\title{
Effect of Financial Literacy on Retirement Preparedness among Employees in the Insurance Sector in Kenya
}

\author{
Emma Aluodi ${ }^{1}$, Amos Njuguna $^{1} \&$ Benard Omboi $^{1}$ \\ ${ }^{1}$ Chandaria School of Business, United States International University, Nairobi, Kenya \\ Correspondence: Emma Aluodi, Chandaria School of Business, United States International University, Nairobi, \\ Kenya.E-mail: ealuodi@gmail.com
}

Received: June 27, 2017

Accepted: September 10, 2017

Online Published: September 17, 2017

doi:10.5539/ijbm.v12n10p242

URL: https://doi.org/10.5539/ijbm.v12n10p242

\begin{abstract}
The failure to comprehend financial matters has been considered the main reason behind retirement problems faced by many individuals. Insurance firms being dominant private player in retirement; the universal assumption is that its' employees have more knowledge of the pension systems and how it affects them. It is equally assumed that these employees are perfectly informed and rely on accurate knowledge regarding their likely retirement benefits and consumption needs and therefore able to arrive at an optimal savings decisions and make better choices for their retirement. This study dissipates this notion after investigating the effect of financial literacy on retirement planning by employees in the insurance sector in Kenya. Using explanatory research design, the study employed stratified proportionate random sampling method to select the respondents. Data was collected using questionnaires and analysed by use of one way ANOVA and Pearson correlational analysis. Hypotheses were tested by use of both, multiple linear regression and multinomial logistic regression. The study reveals that financial literacy has no significant effect on retirement preparedness. This finding offers great insights and implication in policy making for both the government and institutions reforms.
\end{abstract}

Keywords: retirement preparedness, employees, insurance sector, Kenya

\section{Introduction}

The 21 st Century has seen greater numbers of people retiring in their early sixties and even fifties as a result of volatilities in the work and economic environment (Butrica, Smith, \& Toder, 2009). Even in structured savings systems, significant disparity in retirement preparedness is reported due to the ideological differences between defined benefit plans and defined contribution plans, with most sponsors preferring the defined contribution plans to shield themselves from investment risk (Taylor, Funk, \& Clark, 2007; Porterba, Venti, \& Wise, 2007).

Empirical studies have reported inadequacies in retirement preparedness in almost all continents making it become a global social crisis in a context where life expectancy is increasing (Singleton \& Keddy, 1991) the consequence being the aging population being unable to support themselves upon retirement. Complicating the matter is the fact that individuals have been left to absorb idiosyncratic risk associated with their longevity (Porteba et al., 2000). To have better outcomes, individuals must prepare effectively for retirement by accumulating personal savings and equipping themselves with appropriate knowledge to ensure that they are making better savings, investment and personal financial decisions (Lusardi \& Mitchell, 2011). Additionally, there has been rapid change in the performance of financial markets, individual demographics and institutional risk management practices that have placed the financial risks on the ageing individuals (Butrica et al, 2009).

Underscoring the problem, Aegon; a US-based Transamerica Centre for Retirement Studies document growing epidemic of retirement unpreparedness among current workers and retirees in 12 countries in Europe, North America and Asia. Of the 12,000 individuals polled, $12 \%$ were optimistic that they would have sufficient financial resources in retirement. Moreover, $20 \%$ of respondents claimed to have an understanding of financial matters pertaining to effective retirement planning with majority expecting future generations to be worse-off in retirement than current retirees. The findings also indicated that widespread financial retirement illiteracy worsens readiness to retirement. Di Vito and Pospiech (2012), portray financial retirement literacy as a set of behaviour leading to improved financial planning for retirement.

Lack of preparedness for retirement causes psychological distress, strains government support systems in 
countries where such systems exist and generally leads to old age poverty (Lusardi \& Mitchell, 2011). The worrying trend observed by Hershey, Jacobs-Lawson, McArdle, and Hamagami (2007) is that many individuals do not save when they are economically active even though they have the financial resources to do so; a fact that could be attributed to inadequacies in financial literacy. Karniol and Ross (1996) show that an individual who possesses a future time orientation and favorable retirement expectations are more likely to plan and save for retirement. However, individuals who lack financial knowledge may face negative consequences of their financial decisions and are less likely to plan for retirement and are more likely to end up with less wealth close to retirement (Van Rooji, Lusardi, \& Alessie, 2011; Lusardi \& Mitchell, 2007).

Lack of understanding of financial matters has been singled out as the main explanation for investing and savings problems faced by many households (Van Rooij, Lusardi, \& Alessie, 2011). Empirical studies have thus investigated financial literacy and the implications of financial skills and economic knowledge on financial decisions. For instance, Lusardi and Mitchell (2007, 2008, 2009, 2011, and 2013) have over the years been devoted to establish the influence of basic economic concepts on retirement planning and results have exhibited clear relationship between financial skills and knowledge and retirement planning. The studies conclude that a higher degree of financial literacy could potentially contribute to enhancing the financial wellbeing of individuals upon retirement.

The raison $\mathrm{d}$ etre' of the insurance industry is to shield households and firms against risks and help them accumulate savings through life insurance and retirement products. The universal assumption is that insurance firms being dominant private players in retirement; its' employees have more knowledge of the pension systems and how it affects them. It is equally assumed that these employees are perfectly informed and rely on accurate knowledge regarding their likely retirement benefits and consumption needs and therefore able to arrive at an optimal savings decisions and make better choices for their retirement. However, there has been limited research to test this assumption on whether employees' knowledge actually increases their awareness and affects their retirement planning behavior. In fact, Nguya (2015) established that bank employees' high level of financially literacy did not lead to significant impact on their personal financial planning. Therefore, current study sought to establish how financial literacy among working-age cohort within the insurance industry influence the way the plan for their retirement.

This paper is organized as follows; section 2 provides the literature review that informed the study, section three discusses the methodology that was applied, section four provides the results and discussion while sections five and six gives conclusions and recommendations that emanate from the findings.

\section{Literature Review}

\subsection{Retirement Preparedness}

Retirement preparedness is considered an ongoing process of setting aside resources and time so as to provide income at old age with the goal of not just survival but also social inclusion and preservation of human dignity (Keizi, 2006). It requires an individual to analyse current financial situation; identify future financial need, compute the gap and fill by creating asset allocation plan through saving that will generate regular income upon retirement. This process therefore if well planned and carefully executed ensures lots of financial security, peace of mind, relaxation and gain of sense of control over the future (Kapoor, Dlabay, \& Hughes, 1994).

Several studies have suggested different ways to measure preparation for retirement including; proximity (Atchley, 1976; Stawski et al. 2007), pre-retirement involvement scales (Evans et al., 1985), knowledge of retirement issues (Glamser, 1976; 1981), retirement fund calculation and retirement savings (Helman \& Paladino, 2004). Using income replacement rate, Yuh, Montalto, and Hanna (1998) described retirement preparedness as the ability to maintain the pre-retirement level of consumption with retirement resources measured with the income replacement rate. The ratio indicates whether retirees can maintain a reasonable approximation of their pre-retirement consumption level.

Mutran, Reitzes and Fernandez (1997) also measured retirement preparedness by use of questions addressing several topics such as discussing retirement with others; reading about retirement; attending a pre-retirement program, lecture, or seminar; and calculating retirement expenses and income. Lusardi and Mitchell (2009) on the other hand indicate that retirement planning can easily be measured by asking how much respondents have thought about retirement. Equally, Van Rooij et al (2011) relate the amount of thought one has given to retirement to actual and planned saving behaviour and conclude that people who spent more time thinking about retirement are also more likely to plan for future savings. 


\subsection{Financial Literacy}

Financial literacy has been found to be the most important component in achieving a successful adult life as it plays a crucial role in developing not only individuals' financial management attitude, but also attitude about general life (Shim et. al., 2010). According Lusardi \& Mitchell (2013), financial literacy is the ability of an individual to process economic information and make informed decisions about financial planning and wealth accumulation. Previous studies have reported positive effect of financial literacy to financial outcomes such as investment practices and savings (Hilgert, Hogarth \& Beverly, 2003). Mullock and Turcotte (2012) show that, people who are financial literate tend to be more confident of retirement as they understand and accumulate wealth as a way to prepare for retirement. However, some authors argued that individuals are financially illiterate (Lusardi, Mitchell, \& Curto, 2010, Sang, ZatulKaramah, Mail, Jamal, Osman, \& Mohidin, 2014) that consequently affect their financial, investment and retirement planning decision (Lusardi \& Mitchell, 2008; Van Rooij et al., 2011).

Therefore, there has been an increased effort to develop specific measures of financial literacy. Hilgert et al (2003) developed a set of true/false questions to measure financial knowledge and explored the relationship between financial knowledge and money management. Lusardi and Mitchell (2007) developed three set of quiz-like questions testing the understanding of inflation, interest and risk. These set of questions focused on measuring actual knowledge rather than financial experience or decision making skills. The questions were later defined and validated by Hung, Parker, and Yoong (2009) and the extended measure found to be internally consistent, showing good test-retest reliability and stability over time. As a result, these questions have been encompassed in various studies around the globe with Almenberg and Säve-Söderbergh (2011) using similar questions to assess financial literacy in Sweden whereas Klapper and Panos (2011) assessing financial literacy in Russia by use of the same questions. Cole, Shawn, Thomas Sampson, and Bilal Zia (2008) also follow this methodology in measuring literacy in India and Indonesia.

\subsection{Relationship between Financial Literacy and Preparedness for Retirement}

Financial literacy has been discussed at length as one of the factors that influence retirement savings behaviour and has been given prominence as a means of increasing voluntary retirement savings (Van Rooij et al, 2011) because saving for retirement requires people to picture their retirement future. Individuals that are financially illiterate report worse outcomes on their financial, investment and retirement planning decisions (Hilgert et al., 2003; Lusardi et al, 2010, Sang et al., 2014).

Lusardi and Mitchell (2007) studied the relationship between financial literacy and retirement preparedness using the Rand American Life Panel data and found that financial literacy as a key determinant of retirement planning. Adding to this finding, respondents that were exposed to economics in school and to company-based financial education programs had a better understanding of retirement planning than other respondents.

Lusardi and Mitchell $(2008$; 2011) focused on financial literacy and retirement planning by using a National Survey that explored how people manage their resources and make financial decisions. Using this dataset, the authors find that retirement planning and financial literacy are strongly positively associated. The authors asserted that women who are less financially educated are less likely to plan for retirement and be successful planners.

Elsewhere, Bucher-Koenen and Lusardi (2011) examined financial literacy in Germany using data from the SAVE survey and found that knowledge of basic financial concepts was lacking among women, the less educated, and those living in East Germany. The study further compared those with low income and education in the East Germany with their counterparts in the West and found low literacy level and thus accumulates low retirement wealth. They therefore concluded that there was a positive impact of financial knowledge on retirement planning.

In Netherlands, Van Rooij et al. (2011) developed a customized survey with a large set of questions to measure financial literacy and retirement planning confirming that a strong correlation between financial literacy and retirement planning exists. In Malaysia, Mahdzan and Tabiani (2013) surveyed a sample of 200 individuals in to examine the factors that influence individual saving with focus on financial literacy and concluded that people with high financial literacy level are more likely to save as compared to those with low literacy level. Although the results indicate that individuals have a relatively good level of basic financial knowledge, such as computing interest rates and knowledge on relative riskiness of financial assets. The results also found that older people are more likely to have positive saving, holding other factors constant

Klapper and Panos (2011) examine the association of financial literacy with retirement planning in Russia, a 
country they consider relatively old with rapid aging population with large regional disparities using face-to-face interviews of 1,400 individuals and concluded that financial literacy is significantly and positively related to retirement planning. In Kenya, Njuguna and Otsola (2011) sought to assess the levels of financial and pension literacy and to determine the financial literacy needs in a view to recommend the strategies that can be put in place to enhance pension literacy. They used a sample of employees drawn from the members of occupational pension schemes in the Retirement Benefits Authority register. The authors documented an above average literacy level among members of occupational pension schemes in Kenya and recommended need to increase participation in the management of pension schemes. Wachira and Kihiu (2012); Nguya (2015) investigated the effect of financial management and skills on individual decision to save for retirement. Their findings indicated that improvement in the knowledge on financial management and skills led to higher savings for retirement.

\section{Methodology}

This study adopted positivism as its research philosophy. The choice of positivism for this study is justified on the basis that the study set up the hypothesis on the basis of the existing relevant literature and theories. The study adopted the explanatory research design to explain the relationship between the independent variable (financial literacy) and dependent variable (retirement preparedness).

\subsection{Population and Sampling Design}

The study population comprised of employees in the insurance companies in Kenya. The Insurance Regulatory Authority (IRA) provided a list of all 51 licensed insurance firms which reported an estimated 830 permanent and pensionable employees. Proportionate stratified random sampling was used to select a sample of 270 for the study. First, the population was categorized into three strata based on their line of business (general, life or composite). This was done to reduce the risk of the sample consisting of employees from one line of business only. Since each stratum differed vastly in numbers, proportionate sampling was then used to apportion participants so as to ensure each stratum had the same sampling fraction. The participating members were then randomly selected at the data collection stage with a condition to include at least employees in all management level.

\subsection{Measurement of Variables}

To determine the level of financial literacy, two sets of literacy questions were included in the survey. The first set focused on basic levels of financial literacy, including the understanding of: inflation, interest rates, interest compounding and the time value of money. The second set focused on more refined levels of financial literacy which relate to more complex financial instruments, risk diversification and the balancing of risk and return.

Retirement preparedness was measured using two dimensions namely; approximate amount of retirement savings and through self-assessment. By use of amount of savings, individuals were required to indicate their approximate amount of saving from category ranging from less than Ksh. 500,000 to over one million. Through self-assessment, retirement preparedness was measured using a revised version of Stawski, Hershey, and Jacobs-Lawson (2007) planning measure.

\subsection{Data Collection}

The study relied on primary data which was obtained by use of a structured questionnaire that had three sections. The first section sought demographic information of the participants, the second section sought to determine financial literacy levels through a binary measure of literacy advanced by Lusardi \& Mitchell (2007) but questions contextualized to fit the Kenyan scenario (see appendix A) and the third section sought information on preparedness for retirement.

\subsection{Validity and Reliability of the Measuring Instruments}

For financial literacy, evidence by Hung et al. (2009) show that financial literacy scale used by Lusardi and Mitchell (2007), which forms the basis of the questions used in this study, give a good internal consistency (Cronbach Alpha 0.76). Content validity of the questionnaires was also guaranteed by including items that test specific form of knowledge, skills and ability as supported by literature. In addition, items that measured retirement planning questions were equally drawn from empirical studies. Face validity of the measuring instrument was ensured by consulting experts who assisted with the questionnaire design.

\subsection{Ethical Considerations}

To ensure that moral standards were considered in all stages of the research, permission to conduct the study was sought and license granted by National Commission for Science, Technology and Innovation- NACOSTI in Kenya. Similarly, participants were approached and full disclosure of purpose of the study was explained. 


\subsection{Data Analysis}

To determine finance literacy levels, a binary measure of literacy advanced by Lusardi and Mitchell (2007) was adopted which involved contextualizing eight literacy questions which respondents answered and based on their responses; they were categorized into either "low" literacy group for those who score $0-4$ correct answers or "high" literacy group for those who score $5-8$ correct answers. For retirement preparedness, respondents were required to rate their preparedness in response to the statements given on a 5-point Likert scale, where 1 indicated "strongly disagree", 2 indicated "disagree", 3 indicated "indifferent", 4 indicated "agree", and 4 indicated "strongly agree". The score were summed up to compute the total score where higher score indicated higher retirement preparedness. One way ANOVA was used to test whether the means difference between financial literacy scores and retirement preparedness differed significantly. Correlation analysis was used to test the relationship of retirement preparedness and the independent variable. As an extension of the simple correlation, regression analysis were undertaken to test the hypothesised relationship. However, since we predicted the probability of a dependent variable using two dimensions, two regression models were considered to test the hypothesized relationship. In the first option, we measured retirement preparedness using self-assessment dimension (continuous variable) thus leading to the choice of multiple linear regression as appropriate model. In the second option, we predicted the dependent variable being a member of a category thus making the utilization of multinomial logistic regression model as appropriate. To further test for the effect of the moderating variable, the study estimated two regression models (unmoderated and moderated) for each dimension. Similarly, to ensure assumptions of classical linear regression model were not violated, diagnostic tests including multicollinearity, heteroscedasticity and normality were conducted.

\section{Findings and Discussion}

\subsection{Demographic Composition of the Sample}

Table 1 shows that most of the respondents were male (56.7\%), were aged between 31 and 40 years $(45.5 \%)$, had bachelor's degree $(54.6 \%)$, were largely married $(48.1 \%)$, were in the middle management level $(47.4 \%)$, and have worked for 6 to 10 years $(44.4 \%)$.

Table 1. Demographic composition of the sample

\begin{tabular}{lll}
\hline Demographic variable & & Percentage \\
\hline Gender & Male & 56.7 \\
Age & Female & 43.3 \\
& $18-30$ & 41 \\
& $31-40$ & 45.5 \\
& $41-50$ & 11.9 \\
Marital status & $51-60$ & 1.6 \\
& Single & 47.3 \\
& Married & 48.1 \\
Education & Separated/divorced & 3.8 \\
& Widowed & 0.8 \\
& High school & 6.8 \\
& College & 15.9 \\
& Graduate (Bachelors) & 54.6 \\
Management Level & Post Graduate & 22.7 \\
& Top & 45.8 \\
& Middle & 47.4 \\
Work Experience & Lower & 6.8 \\
& $0-5$ & 27.8 \\
& 6 to 10 & 44.4 \\
& 11 to 15 & 17.3 \\
& 16 to 20 & 6.8 \\
& over 20 & 3.7 \\
\hline
\end{tabular}

\subsection{Financial Literacy and Retirement Preparedness}

By use of self-assessment, findings indicated that $46.1 \%$ of working-age individuals within the insurance sector 
in Kenya were confident about their retirement preparedness. However, on the basis of approximate savings, $51.3 \%$ had saved over a million for their retirement. In addition, the overall financial literacy rate amongst the respondents was found to be $64.8 \%$. Regarding the specific literacy questions, $83.3 \%$ of the respondents knew that having Kshs.100 in a savings account with an interest rate of $2 \%$ per year, after 5 years, if they left the money to grow it would increase. Sixty four percent knew that with interest rate of $1 \%$ per year and inflation of $2 \%$ per year, they would be able to buy fewer goods with the money in a year's time. Sixty nine percent knew the correct function of the stock market. Seventy four percent knew that investment in stocks have the highest fluctuation whereas $68.1 \%$ knew bonds normally give the highest return in long term. Finally, $80.4 \%$ knew that when an investor spreads his money among different assets, the risk of losing money decreases. The results indicate an above average literacy rate.

Above results notwithstanding, findings in Table 2 indicate that, financial literacy had no significant effect on retirement preparedness using self-assessment dimension $(p=0.089 ; p>0.05)$. Equally, using approximate amount of saving dimension, results showed that financial literacy had a positive coefficient for all the saving categories, but had no significant effect on retirement preparedness since the p-values were greater than 0.05 (Table 3). Similarly, Pearson coefficient (r) value for financial literacy and retirement preparedness was 0.106 with the value of significant $r$ (2-tailed), $p=.244$ using approximate amount of savings dimension (Table 4) and 0.056 with the value of significant $\mathrm{r}$ (2-tailed), $\mathrm{p}=.561$ (Table 5). ANOVA between financial literacy and retirement using self-assessment dimension was $0.596, \mathrm{p}$ value 0.896 (Table 6) while using approximate amount of saving dimension was $0.559, \mathrm{p}$ value 0.643 (Table 7). Above findings imply that financial literacy has no effect on retirement preparedness among employees in the insurance sector regardless of the dimension used.

Table 2. Coefficients for Effect of Financial Literacy on Retirement Preparedness using self-assessment dimension

\begin{tabular}{|c|c|c|c|c|c|c|}
\hline \multirow[t]{2}{*}{ Mode } & & \multicolumn{2}{|c|}{ Unstandardized Coefficients } & \multirow{2}{*}{$\begin{array}{l}\text { Standardized } \\
\text { Coefficients } \\
\text { Beta }\end{array}$} & \multirow[t]{2}{*}{$\mathrm{t}$} & \multirow[t]{2}{*}{ Sig. } \\
\hline & & B & Std. Error & & & \\
\hline \multirow{2}{*}{2} & Constant & -.174 & .840 & & -.207 & .837 \\
\hline & Financial Literacy & .020 & .012 & .512 & 1.725 & .089 \\
\hline
\end{tabular}

Table 3. Coefficients for Effect of Financial Literacy on Retirement Preparedness using approximate amount of savings dimension

\begin{tabular}{|c|c|c|c|c|c|c|c|}
\hline Approximate saving & & B & Std. Error & Wald & df & Sig. & $\operatorname{Exp}(B)$ \\
\hline \multirow{2}{*}{$100,001-500,000$} & Intercept & -1.975 & 5.082 & .151 & 1 & .698 & \\
\hline & Financial literacy & -.047 & .075 & .398 & 1 & .528 & .954 \\
\hline \multirow{2}{*}{$500,001-1000,000$} & Intercept & -5.641 & 7.045 & .641 & 1 & .423 & \\
\hline & Financial literacy & .061 & .097 & .390 & 1 & .532 & .963 \\
\hline \multirow{2}{*}{ Over $1,000,000$} & Intercept & -30.178 & 19.170 & 2.478 & 1 & .115 & \\
\hline & Financial literacy & -.037 & .118 & .099 & 1 & .753 & 1.063 \\
\hline
\end{tabular}

Table 4. Correlational between Financial Literacy and Retirement Preparedness using approximate amount of savings dimension

\begin{tabular}{lll}
\hline & & Retirement Preparedness \\
\hline \multirow{3}{*}{ Financial Literacy } & Pearson Correlation & .106 \\
& Sig. (2-tailed) & .244 \\
& $\mathrm{~N}$ & 258 \\
\hline
\end{tabular}

Table 5. Correlational between Financial Literacy and Retirement Preparedness using self-assessment dimension

\begin{tabular}{lll}
\hline & & Retirement Preparedness \\
\hline \multirow{3}{*}{ Financial Literacy } & Pearson Correlation & .057 \\
& Sig. (2-tailed) & .561 \\
& $\mathrm{~N}$ & 258 \\
\hline
\end{tabular}


Table 6. ANOVA for Financial Literacy using self-assessment dimension

\begin{tabular}{llllll}
\hline & Sum of Squares & df & Mean Square & F & Sig. \\
\hline Between Groups & 37498.553 & 198 & 382.638 & .596 & 0.896 \\
Within Groups & 5781.250 & 69 & 642.361 & & \\
Total & 43279.803 & 258 & & & \\
\hline
\end{tabular}

Table 7. ANOVA for Financial Literacy using approximate amount of savings dimension

\begin{tabular}{llllll}
\hline & Sum of Squares & df & Mean Square & F & Sig. \\
\hline Between Groups & 806.993 & 140 & 268.998 & .559 & .643 \\
Within Groups & 56832.607 & 118 & 481.632 & & \\
\hline Total & 57639.600 & 258 & & \\
\hline
\end{tabular}

Basically, these results denote that how well an individual understands financial concepts does not necessarily influence the way they prepare for their retirement. Although this finding contradicts various findings such as those of Hastings et al (2011), Van Rooij et al (2011), Lusardi \& Mitchell, (2007, 2008, and 2011) among others, the finding is congruent with Mullock and Turcotte (2012) who made an assessment on financial literacy and its influence on retirement savings decision making in Canada and findings showed that however much the Canadian were characterized with good knowledge of the basic financial characteristic they were still faced with the obvious financial challenges of evaluating risks of investment, financial planning and inflation. This survey results therefore concluded that financial literacy did not make any unique contribution to retirement planning. That despite above average financial literacy, respondents depicted low savings which is likely to cause risks of insufficient wealth to finance consumption after retirement.

Finally, results on the moderating effect of gender on retirement preparedness using self-assessment dimension was significant $(p=0.007)$ but insignificant while using approximate amount of savings dimension $(p=0.052)$. This finding implies that gender has a moderating influence on retirement preparedness when the dimension of self-assessment is used but not when using approximate amount of savings dimension.

\section{Conclusion}

The issue of retirement planning cannot be under emphasized especially in a time when work force aging in developing nations such as Kenya is considered a defining socio-economic concern. In this article, data was used to study how retirement preparedness in Kenya differs among employees in insurance industry with particular focus on the association between financial literacy and retirement preparedness. The study revealed that although proportions of employees who plan for their retirement varied significantly across demographic characteristics, financial literacy amongst the employees was not associated with retirement planning. After controlling for gender, those with the low financial literacy scores were likely just as those with high scores to be confident for retirement. Similar results were obtained when a more subjective saving measure of retirement preparedness was used. This implies that financially illiterate employees in the insurance sector were just as knowledgeable about retirement preparedness as financially literate counterparts and therefore made informed choices about retirement saving and investment. The study therefore concludes that since employees in the insurance sector engage in more financial activity and have access to various financial products and services, most of which are inclined towards retirement, they are able to make financially responsible decisions thereby increasing their retirement confidence. Equally, being in the formal sector, employees in insurances firm are automatically expected to contribute to mandatory social security fund which acts like a potential safety net and in addition employer pension fund which provides the bulk of the retirement funding. Therefore, since retirement contributions are usually a percentage of their salary, it can be concluded that retirement savings is not influenced by employee's financial literacy rate but rather their income level.

\section{Limitations of the Study}

The data used in the analysis of individuals' savings were obtained by means of self-report. That being the case, those reports may have been either inaccurate or biased in a self-serving fashion and therefore the study findings cannot be generalized to all insurance employees in Kenya.

\section{Recommendations}

These findings call for policy makers to formulate and implement customized literacy programs that not only capture general financial decision through arithmetic but rather focus specifically on long term financial 
planning. Such programs would then stimulate extra saving and investment by employees in addition to those presented by their work environment. The study suggests longitudinal research efforts to be devoted to selected sample over a specified period of time to assess similar relationship. Finally, a replication of the study with respondents being drawn from different sector of the economy is equally recommended.

\section{References}

Ade, D. P. (2013). The Effect Of Financial Literacy On Pension Preparedness Among Members Of The Informal Sector In Kenya, Unpublished MBA project, UoN, Nairobi

Almenberg, J., \& Jenny, S. (2011). Financial Literacy and Retirement Planning in Sweden. CeRP Working Paper, 112. http://dx.doi.org/10.2139/ssrn.1809736

Atchley, R. (1976). The sociology of retirement. Cambridge, M.A.: Schenkman Publishing Co.

Bucher-Koenen, T., \& Lusardi, A. (2011). Financial Literacy and Retirement Planning in Germany, Journal of Pension Economics and Finance, 10(4), 565-584.

Butrica, B., Smith, K., \& Toder, E. (2009). Retirement Security and the Stock Market Crash: What are the Possible Outcomes? Working Paper 2009-30, Center for Retirement Research, Boston College. Retrieved from http://www.tandfonline.com/doi/abs/10.1080/08959420.2010.507623? journalCode=wasp20

Cole, S., Thomas, S., \& Bilal, Z. (2011). Money or knowledge? What drives the demand for financial services in developing countries? Harvard Business School Working Paper, No. 09-117. Retrieved from http://personal.lse.ac.uk/sampsont/PricesKnowledge.pdf

Evans, L., Ekerdt, D., \& Bosse, R. (1985). Proximity to retirement and anticipatory involvement: Findings from the normative aging study. Journal of Gerontology, 40, 368-374.

Hastings, J., Madrian, B., \& Skimmyhorn, W. (2013). Financial Literacy, Financial Education, and Economic Outcomes. Annual Review of Economics, 5(1), 347-373. Retrieved from https://www.ncbi.nlm.nih.gov/pmc/articles/PMC3753821/

Helman, R., \& Paladino, V. (2004). Will Americans ever become savers? The 14th Retirement Confidence Survey, Issue Brief 268. Washington D.C.: Employee Benefit Research Institute. Retrieved from https://www.ncbi.nlm.nih.gov/pubmed/15101234

Hershey D. A., Jacobs-Lawson J. M., McArdle J. J., \& Hamagami A. (2007). Psychological foundations of financial planning for retirement. Journal of Adult Development, 14, 26-36. Retrieved from https://link.springer.com/article/10.1007/s10804-007-9028-1

Hilgert, M. A., Hogarth, J. M., \& Beverly, S. G. (2003). Household financial management: The connection between knowledge and behavior. Federal Reserve Bulletin, 309-322

Hung, A. A., Parker, A. M., \& Yoong, K. K. (2009). Defining and Measuring Financial Literacy. RAND Working Paper WR-708. http://dx.doi.org/10.2139/ssrn.1498674

Huston, S. J. (2010). Measuring financial literacy. Journal of Consumer Affairs, 44(2), 296-316. Retrieved from http://onlinelibrary.wiley.com/doi/10.1111/j.1745-6606.2010.01170.x/abstract

Kapoor, J., Dlabay, L., \& Hughes, R. (1994). Personal Finance; Retirement Planning. Woodland Hills, Calif.: McGraw Hill/Glencoe.

Karniol, R., \& Ross, M. (1996). The motivational impact of temporal focus: Thinking about the future and the past. Annual Review of Psychology, 47, 593-620.

Keizi, L. K. (2006). Barriers to Pension Scheme Participation by Workers in the Informal Economy. International Organisation of Pension Supervisor, (1) 12-20

Klapper, L., \& Panos, G. (2011). Financial Literacy and Retirement Planning in View of a Growing Youth Demographic: the Russian Case. CeRP Working Paper, No. 114/11 http://dx.doi.org/10.2139/ssrn.1809723

Lusardi, A. (2009). Planning for retirement: The importance of financial literacy. Public Policy \& Aging Report, 19(3), 7-13. Retrieved from http://www.dartmouth.edu/ alusardi/Papers/PPAR09.pdf

Lusardi, A., \& Mitchell, O. S. (2007). Baby Boomer retirement security: The roles of planning, financial literacy, and housing wealth. Journal of Monetary Economics, 54, 205-224. http://www.nber.org/papers/w12585

Lusardi, A., \& Mitchell, O. S. (2008). Planning and financial literacy: How do women fare? American Economic Review: Papers \& Proceedings, 98(2), 413-417. https://doi.org/10.3386/w13750 
Lusardi, A., \& Mitchell, O. S. (2011a). Financial literacy and planning: Implications for retirement wellbeing. Working Paper, 1, 70-78. https://doi.org/10.3386/w17078

Lusardi, A., \& Mitchell, O. S. (2011b). The economic importance of financial literacy: theory and evidence.Working Paper, 1,70-78. https://doi.org/10.3386/w18952

Lusardi, A., \& Olivia, S. (2011c). Financial Literacy and Retirement Planning in the United States. CeRP Working Papers. Center for Research on Pensions and Welfare Policies, Turin (Italy). https://doi.org/10.3386/w17108

Lusardi, A., Mitchell, O. S., \& Curto, V. (2010). Financial literacy among the young. Journal of Consumer Affairs, 44(2), 358-380. https://doi.org/10.3386/w15352

Mahdzan, N. S., \& Tabiani, S. (2013). The Impact of Financial Literacy on Individual Saving: An Exploratory Study in the Malaysian Context. Transformations in Business and Economics, 121(28), 41-55. Retrieved from http://www.transformations.knf.vu.lt/28/se28.pdf

Mullock, K., \& Turcotte, J. (2012). Financial Literacy and Retirement Saving. Working Paper, 1, Department of Finance, Canada.

Mutran, E. J., Reitzes, D. C., \& Fernandez, M. E. (1997). Factors that influence attitudes toward retirement. Research on Aging, 19, 251-273. https://doi.org/10.1177/0164027597193001

Nguya, M. M. (2015). Evaluation of the relationship between financial literacy and retirement planning.

Njuguna, A. G., \& Otsola, J. (2011). Predictors of Pension Finance Literacy: A Survey of Members of Occupational Pension Schemes in Kenya. International Journal of Business Management, 6(9), 101-112. https://doi.org/10.5539/ijbm.v6n9p101

Poterba, J. M., Steven, F. V., \& David, A. W. (2000). Lump Sum Distributions from Retirement Savings Plans: Receipt and Utilization. Chicago: University of Chicago Press.

Poterba, J., Rauh, J., Venti, S., \& Wise, D (2007). Defined Contribution Plans, Defined Benefit Plans, and the Accumulation of Retirement Wealth. Journal of Public Economics, 91, 2062-2086. https://doi.org/10.1016/j.jpubeco.2007.08.004

Sang, L. T., Zatul K, Mail, R., Jamal, A., Osman, Z., \& Mohidin, R. (2014). An Investigation of the Level and Determinants of Financial Literacy among Different Groups in Sabah. Universiti Malaysia Sabah, Malaysia

Shim, S., Barber, B. L., Card, N. A., Xiao, J. J., \& Serido, J. (2010). Financial socialization of first-year college students: The roles of parents, work, and education. Journal of Youth and Adolescence, 39(12), 1457-1470. https://doi.org/10.1007/s10964-009-9432-x

Singleton, J., \& Keddy, B. (1991). Planning for retirement. Activities, Adaptation \& Aging, 16, 49-55.

Stawski, R. S., Hershey, D. A., \& Jacobs-Lawson, J. M. (2007). Goal clarity and financial planning activities as determinants of retirement savings contributions. International Journal of Aging and Human Development, 64(1), 13-32. https://doi.org/10.2190/13GK-5H72-H324-16P2

Taylor, P., Funk, C., \& Clark, A. (2007). Generation gap in values, behaviors: As marriage and parenthood drift apart, public is concerned about social impact. Pew Research Center, Washington, DC.

Van Rooij, M., Lusardi, A., \& Alessie, R. (2011). Financial Literacy, Retirement Preparation and Pension Expectations in the Netherlands. Working Papers. Center for Research on Pensions and Welfare Policies, Turin, Italy. Retrieved from https://www.dnb.nl/en/binaries/working\%20paper\%20313_tcm47-257145.pdf

Wachira, M. I., \& Kihiu, E. N. (2012). Impact of financial literacy on access to financial services in Kenya. International Journal of Business and Social Science, 3(19). http://ijbssnet.com/journals/Vol_3_No_19_October_2012/5.pdf

Yuh, Y., Montalto, C. P., \& Hanna, S. (1998). Are Americans prepared for retirement? Financial Counselling and Planning, 9(1), 1-12. https://doi.org/10.1.1.41.3277\&rep=rep1\&type=pdf

\section{Appendix A: Lusardi and Michelle (2007) Financial Literacy Questions \\ Basic financial literacy questions}

1) Suppose you had $€ 100$ in a savings account and the interest rate was $2 \%$ per year. After 5 years, how much do you think you would have in the account if you left the money to grow? (i) More than $€ 102$; (ii) Exactly $€ 102$; (iii) Less than $€ 102$; (iv) Do not know; (v) Refusal. 
2) Suppose you had $€ 100$ in a savings account and the interest rate is $20 \%$ per year and you never withdraw money or interest payments. After 5 years, how much would you have on this account in total? (i) More than $€$ 200; (ii) Exactly $€ 200$; (iii) Less than $€ 200$; (iv) Do not know; (v) Refusal.

3) Imagine that the interest rate on your savings account was $1 \%$ per year and inflation was $2 \%$ per year. After 1 year, how much would you be able to buy with the money in this account? (i) More than today; (ii) Exactly the same; (iii) Less than today; (iv) Do not know; (v) Refusal.

4) Assume a friend inherits $€ 10000$ today and his sibling inherits $€ 100003$ years from now. Who is richer because of the inheritance? (i) My friend; (ii) His sibling; (iii) They are equally rich; (iv) Do not know; (v) Refusal.

5) Suppose that in the year 2010, your income has doubled and prices of all goods have doubled too. In 2010, how much will you be able to buy with your income? (i) More than today; (ii) The same; (iii) Less than today; (iv) Do not know; (v) Refusal.

\section{Advanced financial literacy questions}

6) Which statement describes the main function of the stock market? (i) The stock market helps to predict stock earnings; (ii) The stock market results in an increase in the price of stocks; (iii)The stock market brings people who want to buy stocks together with those who want to sell stocks; (iv) None of the above; (v) Do not know; (vi) Refusal.

7) What happens if somebody buys the stock of firm B in the stock market? (i) He owns a part of firm B; (ii) He has let money to firm B; (iii) He is liable for firm B debt; (iv) None of the above; (v) Do not know; (vi) Refusal.

8) Which statement about mutual funds is correct? (i) Once one invests in a mutual fund, one cannot withdraw the money in the first year; (ii) Mutual funds can invest in several assets, for example invest in both stocks and bonds; (iii) Mutual funds pay a guaranteed rate of return which depends on their past performance; (iv) None of the above; (v) Do not know; (vi) Refusal.

9)What happens if somebody buys a bond of firm B?(i) He owns a part of firm B; (ii) He has lent money to firm B; (iii) He is liable for firm B's debts; (iv) None of the above; (v) Do not know; (vi) Refusal.

10) Considering a long time period (for example 10 or 20 years), which asset normally gives the highest return: (i) Savings accounts; (ii) Bonds; (iii) Stocks; (iv) Do not know; (v) Refusal.

11) Normally, which asset displays the highest fluctuations over time: (i) Savings accounts; (ii) Bonds; (iii) Stocks; (iv) Do not know; (v) Refusal.

12) When an investor spreads his money among different assets, does the risk of losing money (i) Increase; (ii) Decrease; (iii) Stay the same; (iv) Do not know; (v) Refusal.

13) If you buy a 10 -year bond, it means you cannot sell it after 5 years without incurring a major penalty. (i)True; (ii) False; (iii) Do not know; (iv) Refusal.

14) Stocks are normally riskier than bonds. (i) True; (ii) False; (iii) Do not know; (iv) Refusal.

15) Buying a company fund usually provides a safer return than a stock mutual fund. (i)True; (ii) False; (iii) Do not know; (iv) Refusal.

16) If the interest rate falls, what should happen to bond prices: (i) Rise; (ii) Fall; (iii) Stay the same; (iv) None of the above; (v) Do not know; (vi) Refusal.

\section{Copyrights}

Copyright for this article is retained by the author(s), with first publication rights granted to the journal.

This is an open-access article distributed under the terms and conditions of the Creative Commons Attribution license (http://creativecommons.org/licenses/by/4.0/). 